\title{
The Proteome Response of Salt-Sensitive Rapeseed (Brassica napus L.) Genotype to Salt Stress
}

\author{
Nima DOLATABADI, Mahmoud TOORCHI*, Mostafa VALIZADEH, \\ Ali BANDEHAGH
}

\author{
University of Tabriz, Faculty of Agriculture, Department of Plant Breeding and Biotechnology, Imam Khomeini Street, Tabriz, \\ Iran;nima_d82@yahoo.com;mtoorchi@tabrizu.ac.ir ("correspondingauthor);mvalizadeh@tabrizu.ac.ir; bandehhagh@yahoo.com
}

\begin{abstract}
Productivity of rapeseed (Brassica napus L.), the third most important oilseed crop, was reduced more than other crops under the salt stress higher than the threshold. Thus, breeding, especially at seedling stage, seems necessary. Plants under salt stress, by synthesis of essential metabolites, specific structural proteins or enzymes of metabolic pathways deal with the stress. To identify the molecular mechanisms of salt responsiveness in rapeseed, 'Option 500 ' a salt-sensitive genotype was exposed to 0,150 , and $300 \mathrm{mM} \mathrm{NaCl}$ during the seedling stage. An increase in proline and the $\mathrm{Na}^{+}$content of leaf and a reduction in shoot dry weight, plant height, $\mathrm{K}^{+}$content and $\mathrm{K}^{+} / \mathrm{Na}^{+}$ratio were observed. Protein expression changes were examined by twodimensional electrophoresis (2-DE). Out of 110 protein spots identified by 2-DE gels, 37 spots showed significant abundant changes based on induction factor (IF), and 7 spots were recognized significantly at 5\% probability level, which 1 and 6 spots were up and down-regulated, respectively. By using LC-MS/MS mass spectrometry analysis, proteins were identified which are involved in energy production and photosynthesis. Activity of enzymes involved in energy production decreased under stress, while the abundance of Phosphoribulokinase (PRK) -an important enzyme in the pentose phosphate pathway- increased.
\end{abstract}

Keywords: abiotic stress; proteomics; rapeseed; salinity; two-dimensional electrophoresis

\section{Introduction}

Soil salinity is a global problem that through the effect on plant growth and limiting exploitation of agricultural lands has restricted the productions of agricultural crops (Joseph et al., 2010). Salinity as one of the most important abiotic stresses in arid and semi-arid areas reduces the average of crop yield about 50\% (Kandil et al., 2012). Oil seeds have the third place in the human food needs after cereals and beans. And in the meantime, oily species of Brassica are allocated the third place among oil seeds (Shirazi et al., 2011). Rapeseeds with high proteins and lipids and due to the low amount of saturated fatty acids (less than $4 \%$ palmitic acid) and a relatively large amount of oleic acid (60\%) and $\alpha$-Linolenic acid (9\%), in comparison to sunflower, maize and soybean oils have high nutritional quality (Gunstone, 2004). For optimal use of the saline soils, salinity control through planting tolerant genotypes is one of the basic strategies, because soil remediation needs more time and it is not economical (Purty et al., 2008). Since soil and water salinity are the most important limiting factors of Rapeseed production, breeding and using the tolerant genotypes to salt stress can be a good strategy to preserve the production levels in the face of salinity stress (Ashraf and Akram, 2009).

Salinity reduces or delays the germination of most crops (Farhoudi and Sharifzadeh, 2006; Benincasa et al., 2013). It also reduces some traits such as root length, shoot height, root and shoot dry weight and leaf area index at seedling stage (Miyamoto et al., 2012; Haq et al., 2014). Although, salinity affects all stages of plant growth, but germination and seedling stages are known as the most critical stages in most crop species (Munns, 2002).

The rate of photosynthesis and transpiration, stomatal conductance, chlorophyll content and leaf area decreased while sodium content of soil increasing. Reducing the rate of photosynthesis under salt stress can be happen due to a reduction in stomatal conductance, impaired metabolic processes, especially in carbon absorption, inhibition of photochemical capacities or a combination of all items (Ashraf and McNeilly, 2004). Losses of cell turgor, as the result of decreasing soil water potential, cause stomata closure and therefore reduce the rate of photosynthesis (Gul et al., 2014). The synthesis of chlorophyll is affected by high salt concentration and the salt effects on the synthesis of chlorophyll (a) are much greater (Jamil et al., 2014). 
High concentrations of cations such as $\mathrm{Na}^{+}$which is the most common element of salinity can disrupt the biochemical processes in plant tissues, or they can prevent their works and change the synthesis of required proteins quantitatively and qualitatively, which in turn disrupt growth process (Ashraf and McNeilly, 2004). On the other hand, a high concentration of sodium disturbs the nutritional balance and also causes ionic toxic and osmotic regulation disorder. In response to salt stress, osmotic adjustment or the accumulation of organic compounds (e.g., proline) and minerals (such as $\mathrm{Na}^{+}$and $\mathrm{K}^{+}$) occurs in cells that causes absorption of water into the cells and saves cells turgor (Nayyar, 2003; Shirazi et al., 2011). Soluble organic compounds such as sugars, organic acids, polyols and many compounds containing nitrogen such as amino acids, amides, proteins and ammonium compounds are involved in osmotic adjustment and enzymatic activity of plant species. Therefore, such organic osmotic compounds can play a key role in the tolerance to salt stress (Ashraf and McNeilly, 2004). By studying the effect of salinity on plants and plant's response to stress, it can be assumed that the free amino acids have more critical role than other organic soluble osmotic compounds (Giannakoula and Ilias, 2013). Also proline has found more than other amino acids in plants under stress and this amino acid plays an important role in adjusting the accumulation of usable nitrogen, osmotic adjustment and membrane stability (Parida and Das, 2005).

Environmental stresses usually cause protein disorders (Joseph and Jini, 2010). Plants that face stress conditions, synthesize some essential metabolites to overcome the situation (Turan et al., 2012). This action is performed by changing the expression of genes in order to reduce or increase the amount of specific structural proteins or enzymes of metabolic pathways (Joseph et al., 2010). Proteomics approach is a powerful and suitable tool to examine the expression changes and to identify the proteins that respond to abiotic stresses (Sobhanian et al., 2011). Proteomics analysis has been reported as one of the best strategies to study the dynamic expression of proteins under salt stress (Guo et al., 2012). Comparative proteomics of plants before and after stress have given a lot of information about the tolerant mechanisms of plants against environmental stresses (Kamal et al., 2010).

This study was designed and performed to improve our understanding of physiological mechanisms of salt tolerance in rapeseed at seedling stage by exploring and identifying changes that occur in the structural proteins or enzymes in metabolic pathways under salinity by use of proteomic approaches. For identification of proteins and molecular pathways involved in the development of tolerance to salinity and determining candidate genes, the LC-MS/MS mass spectrometry technique was used.

\section{Materials and Methods}

\section{Plant material and growth conditions}

In this study, susceptible spring rapeseed 'Option500' (Dolatabadi $e t$ al., 2016) which obtained from Seed and Plant Improvement Institute (SPII) Karaj-Iran, was evaluated under salt stress at seedling stage by using hydroponic culture which they were irrigated four times daily with a modified Hogland nutrient solution. Three levels of $\mathrm{NaCl}$ salinity (zero (control), 150 and $300 \mathrm{mM}$ ) was applied gradually ( $50 \mathrm{mM}$ per day) one week after planting the plantlets.

\section{Physiological traits analysis}

Twenty-eight days after exposure to salt stress, and at the end of the seedling stage, shoot dry weight, plant height, content of leaf proline, sodium and potassium were measured. To measure proline, samples of leaf number three were frozen by liquid nitrogen and were transferred into the $-80{ }^{\circ} \mathrm{C}$ freezer. Proline content of leaf was measured by ninhydrin method (Bates, 1973). Dry weight of samples was determined after drying at $75^{\circ} \mathrm{C}$ for 48 hours. The dried samples were used to measure $\mathrm{Na}^{+}$and $\mathrm{K}^{+}$content. The samples were solved in nitric acid $(7.2 \mathrm{~N})$ and heated on hot plate. Sodium and potassium ions were measured by flame photometer.

\section{Statistical analysis}

Analysis of variance was performed in randomized complete block design with three replications and Duncan's multiple range tests were used for the means comparison. Statistical analyses were performed by MSTATC, IBM SPSS Statistics v21 and Excel computer programs.

\section{Protein extraction and two-dimensional electrophoresis}

Samples of leaf number three under the zero and 300 $\mathrm{mM}$ treatment of sodium chloride, in three replications were packed in aluminum foil separately and frozen in liquid nitrogen and kept in a $-80^{\circ} \mathrm{C}$ freezer until the protein extraction. Leaves total protein extraction were done by TCA/acetone method (Salekdeh et al., 2002). In this method, $0.5 \mathrm{~g}$ of frozen leaf samples were powdered and dissolved in lysis buffer (7M urea, $2 \mathrm{M}$ thiourea, $2 \%$ CHAPS, $1 \%$ ampholyte ( $\mathrm{pH}: 3-10)$ and $60 \mathrm{mM}$ DDT) by centrifuging at $20000 \mathrm{~g}$ for $20 \mathrm{~min}$ at $25^{\circ} \mathrm{C}$. To determine protein concentrations Bradford method (Bradford, 1976) was used. The protein extract $(400 \mu \mathrm{g}, 100 \mu \mathrm{L})$ was separated by 2-DE. The first dimension electrophoresis was performed by $11 \mathrm{~cm}$ length and $3 \mathrm{~mm}$ diameter with $8 \mathrm{M}$ urea, $3.5 \%$ polyacrylamide, $2 \%$ NP- $40,2 \%$ ampholyte $(\mathrm{pH}$ : 3-10 and 5-8), ammonium persulfate and tetramethylethylenediamine (TEMED) IEF tube gels. The first dimension electrophoresis was done in three-phase $(200 \mathrm{~V}$ for 30 minutes, $400 \mathrm{~V}$ for 16 hours and 600 volts for 1 hour). The second dimension was done by SDS-PAGE method using 15\% polyacrylamide separating gel and 5\% acrylamide stacking gel for about 3 hours at $35 \mathrm{~mA}$. The gels were stained with Coomassie brilliant blue (G-250).

\section{Image analysis and protein identification}

The 2-DE gels were scanned with GS-800 (Bio-Rad) and analyzed with PDQuest ver. 8.0.1 (Bio-Rad). Spots with significant expression changes were identified by Student's $t$-test. After identifying protein spots with significant differential abundant, the spots were sent to Alberta Proteomics and Mass Spectrometry Facility for mass spectrometry analyzing. Protein spots were identified by LC-MS/MS mass spectrometry method and Sequest software. Combined LC-MS/MS selections with the searches of UniprotKB database were used to the final identification of the proteins. 


\section{Results}

Between salinity levels, in all traits significant differences were observed (Table 1). Variance analysis showed that the differences between salinity levels in all traits were significant at $5 \%$ probability. Changes in the traits under salinity are shown in Fig. 1. In $300 \mathrm{mM}$, highest content of proline and, in control condition, lowest content have been observed (Fig. 1). Two-dimensional electrophoresis of genotypes and protein spots analysis by using PDQuest software led to the identification of 110 repeatable protein spots in gels (Fig. 2). 44 spots among identified 110 spots, based on IF index, showed significant abundant changes, and after Student's $t$-test, seven protein spots were significantly changed at 5\% probability level, which spot 2405 was up-regulated and spots 3102, 3502, 4104, 4303, 8404 and 8501 were down-regulated (Fig. 3). The detected proteins which were identified by LC-MS/MS mass spectrometry were involved in energy production and photosynthesis (Table 2). Spot 2405 which had increased the abundant under salt stress was probably Phosphoribulokinase (PRK) that was involved in the production cycle of carbohydrates (Caruso et al., 2008). Spots 3502 and 4303, respectively, were related to beta and alpha subunits of chloroplast ATP synthase which involve in the production of ATP (Kang et al., 2012). Spot 4104 was related to Triosephosphate isomerase (TPI) which plays a key role in the energy production cycle (Sharma et al., 2012). Spot 8404 which related to Glyceraldehyde-3phosphate dehydrogenase is involved in carbon dioxide pathway (Tanou et al., 2009). Spot 8501 which was identified as ribulose -1,5 - bisphosphate carboxylase /oxygenase (RuBisCO), has a key role in the stabilization cycle of carbon dioxide (Guo et al., 2012). Spot 3102 which showed an expression reduction under salt stress, although have been reported on rapeseed previously, and it has an access code in UniprotKb database, but still not identified very well (Table 2). Identifying its structure and function precisely, certainly will help to better understand the rapeseed's tolerance mechanism to salt stress

Table 1. Analysis of variance for studied traits in 'Option500' under salinity treatments

\begin{tabular}{|c|c|c|c|c|c|c|c|}
\hline \multirow{2}{*}{ Source of Variance } & \multirow{2}{*}{ Degrees of Freedom } & \multicolumn{6}{|c|}{ Mean Square } \\
\hline & & Shoot Dry Weight & Shoot Height & Leaf $\mathrm{Na}^{+}$ & Leaf $\mathrm{K}^{+}$ & Leaf $\mathrm{K}^{+} / \mathrm{Na}^{+}$ & Leaf Proline \\
\hline Replication & 2 & $0.008^{\text {ns }}$ & $5.7^{\mathrm{ns}}$ & $271.3^{\mathrm{ns}}$ & $217.9^{\mathrm{ns}}$ & $0.488^{\mathrm{ns}}$ & $468.7^{\mathrm{ns}}$ \\
\hline Salinity $(S)$ & 2 & $0.264^{*}$ & $136.7^{*}$ & $16856.8^{* *}$ & 805.6 & $22.2^{*}$ & $2056.6^{* *}$ \\
\hline Error & 4 & 0.022 & 12.9 & 323.712 & 67.040 & 0.431 & 105.312 \\
\hline $\mathrm{CV} \%$ & & 38.78 & 19.27 & 21.02 & 28.95 & 37.92 & 26.96 \\
\hline
\end{tabular}

* Significant at the $5 \%$ probability level; ${ }^{* *}$ significant at the $1 \%$ probability level; ns: Not significant.

Table 2. Identification of differentially abundant proteins of 'Option500' after salt stress

\begin{tabular}{|c|c|c|c|c|c|c|c|c|c|c|c|}
\hline $\begin{array}{c}\text { Spot } \\
\text { ID }\end{array}$ & Protein name & $\begin{array}{l}\text { Accession } \\
\text { number }^{\mathrm{a}}\end{array}$ & $\begin{array}{c}\text { Reference } \\
\text { species }\end{array}$ & $\begin{array}{c}\text { Cov. }(\%) \\
\text { b }\end{array}$ & $\begin{array}{c}\text { Score } \\
c\end{array}$ & $\begin{array}{l}\text { Theo. } \\
\mathrm{pI} / \mathrm{MW}\end{array}$ & $\begin{array}{c}\text { Exp. } \\
\mathrm{pl} / \mathrm{MW}\end{array}$ & $\mathrm{IF}^{\mathrm{d}}$ & $\begin{array}{c}\text { UPs }^{\mathrm{e}} / \\
\mathrm{Ps}^{\mathrm{f}}\end{array}$ & $\begin{array}{l}\text { PSMs }^{g} \\
/ \mathrm{AAs}^{\mathrm{h}}\end{array}$ & Function \\
\hline 2405 & Phosphoribulokinase & A0A078GC16 & Brassica napus & 72.29 & 762.17 & $5.77 / 44.4$ & $5.5 / 41.30$ & 14.46 & $3 / 21$ & $\begin{array}{c}301 / 3 \\
97\end{array}$ & $\begin{array}{c}\text { Carbohydrate } \\
\text { metabolic }\end{array}$ \\
\hline 3102 & $\begin{array}{l}\text { BnaA09g07850D } \\
\text { protein }\end{array}$ & A0A078FW31 & Brassica napus & 40.93 & 21.27 & $5.72 / 23.5$ & $5.92 / 22.05$ & 0.48 & $6 / 6$ & $7 / 215$ & Unknown \\
\hline 3502 & $\begin{array}{l}\text { ATP synthase subunit } \\
\text { beta, chloroplastic }\end{array}$ & D1L8P5 & Brassica napus & 36.75 & 42.02 & $5.26 / 53.7$ & $5.82 / 50.68$ & 0.19 & $12 / 12$ & $\begin{array}{c}14 / 49 \\
8\end{array}$ & ATP synthesis \\
\hline 4104 & $\begin{array}{c}\text { Triosephosphate } \\
\text { isomerase }\end{array}$ & A0A078CJ83 & Brassica napus & 65.35 & 94.13 & $5.73 / 27.2$ & $6.03 / 24.96$ & 0.39 & $4 / 13$ & $\begin{array}{c}37 / 25 \\
4\end{array}$ & Glycolytic \\
\hline 4303 & $\begin{array}{l}\text { ATP synthase subunit } \\
\text { alpha, chloroplastic }\end{array}$ & D1L8M3 & Brassica napus & 13.41 & 11.81 & $5.20 / 55.3$ & $6.08 / 38.02$ & 0.32 & $5 / 5$ & $5 / 507$ & ATP synthesis \\
\hline 8404 & $\begin{array}{c}\text { Glyceraldehyde-3- } \\
\text { phosphate } \\
\text { dehydrogenase }\end{array}$ & A0A078EFC4 & Brassica napus & 40.85 & 591.80 & $7.75 / 42.7$ & $7.31 / 43.20$ & 0.20 & $5 / 15$ & $\begin{array}{c}215 / 3 \\
99\end{array}$ & $\begin{array}{l}\text { Glucose } \\
\text { metabolic }\end{array}$ \\
\hline 8501 & $\begin{array}{c}\text { Ribulose-1,5- } \\
\text { bisphosphate } \\
\text { carboxylase/oxygenase } \\
\text { large subunit }\end{array}$ & Q71SX0 & Brassica napus & 56.58 & 637.91 & $6.29 / 52.9$ & $6.62 / 52.76$ & 0.22 & $27 / 27$ & $\begin{array}{c}236 / 4 \\
79\end{array}$ & $\begin{array}{l}\text { Carbon } \\
\text { fixation }\end{array}$ \\
\hline $\begin{array}{l}\text { a Access } \\
\text { b Percer } \\
\text { c Seques } \\
\text { d Induc } \\
\text { e Uniqu } \\
\text { f All uni } \\
\text { g Peptid } \\
\text { h Numb }\end{array}$ & $\begin{array}{l}\text { n number according to } \\
\text { ge of the protein seque } \\
\text { core } \\
\text { n Factor (\%volume of } \\
\text { eptides identified whi } \\
\text { e peptide plus peptide } \\
\text { Pectral Matches. PSN } \\
\text { of amino acids in the }\end{array}$ & $\begin{array}{l}\text { JniprotKb data } \\
\text { ce covered by th } \\
\text { otein in stress c } \\
\text { only occur in tl } \\
\text { hat may be com } \\
\text { are roughly pro } \\
\text { act protein (the }\end{array}$ & $\begin{array}{l}\text { ase (www.unip } \\
\text { matching pept } \\
\text { dition / \% vol } \\
\text { protein identi } \\
\text { on between th } \\
\text { ortional to pro } \\
\text { etical). }\end{array}$ & $\begin{array}{l}\text { t.org). } \\
\text { es. } \\
\text { ne of prote } \\
\text { d. } \\
\text { or more p. } \\
\text { n abundan }\end{array}$ & $\begin{array}{l}\text { in cont } \\
\text { eins. }\end{array}$ & condition) & & & & & \\
\hline
\end{tabular}


20
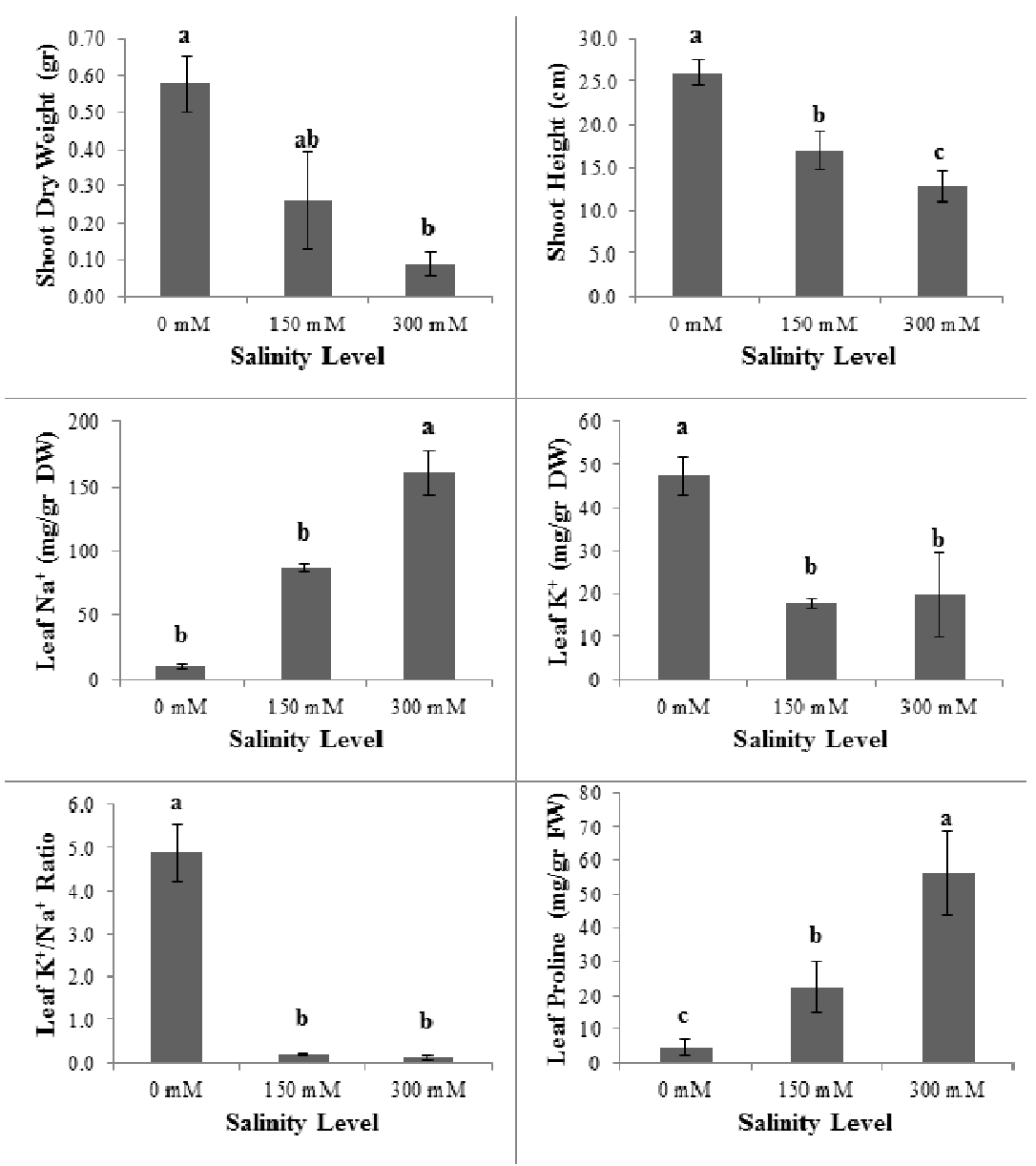

Fig. 1. Effects of salt stress $(0,150$ and $300 \mathrm{mM} \mathrm{NaCl})$ on shoot dry weight, shoot height, Leaf $\mathrm{Na}^{+}$, Leaf $\mathrm{K}^{+}$, Leaf $\mathrm{K}^{+} / \mathrm{Na}^{+}$ratio and Leaf Proline of optioon500. Columns with the same letters are not significantly different at $(\mathrm{P}>0.05)$ levels by Duncan's multiple range test

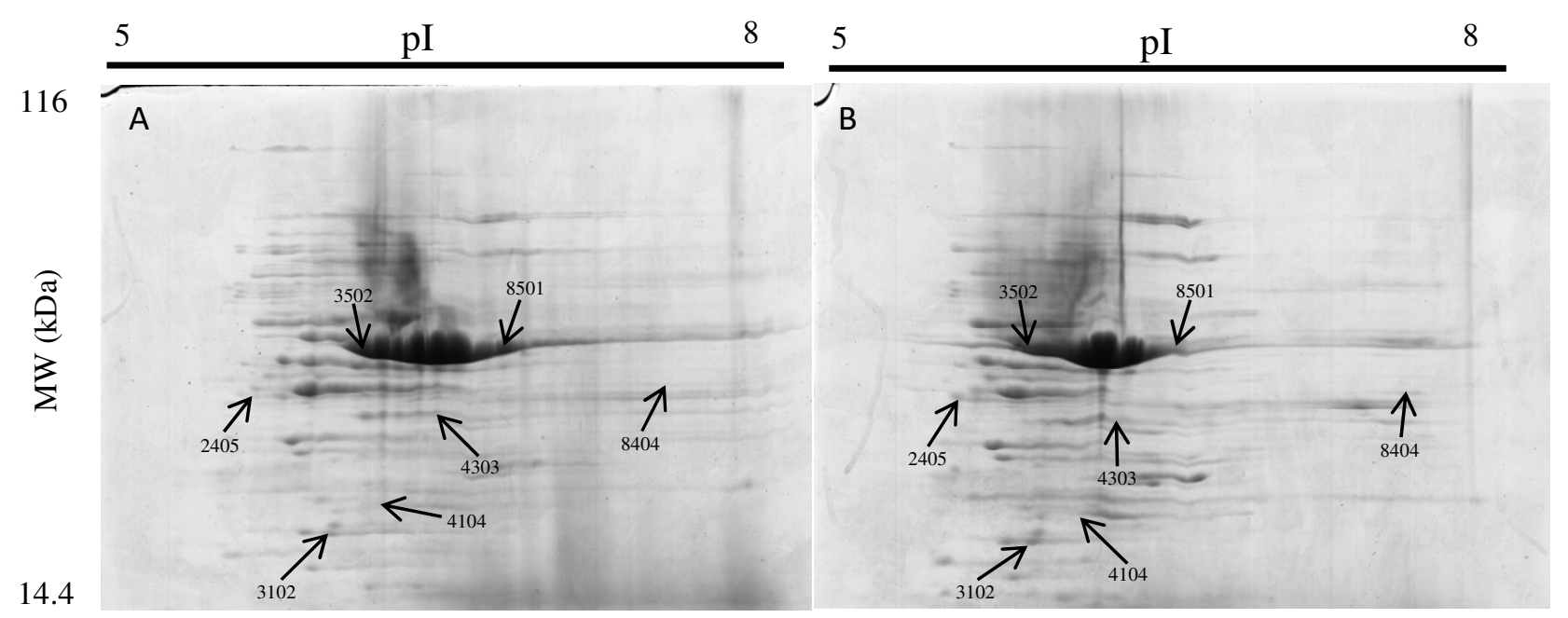

Fig. 2. Representative 2-DE gels of 'Option500' leaves under 0 (A) and $300 \mathrm{mM}$ (B) $\mathrm{NaCl}$ treatment. Numbered spots correspond to salt-responsive proteins, which analyzed by LC-MS/MS 


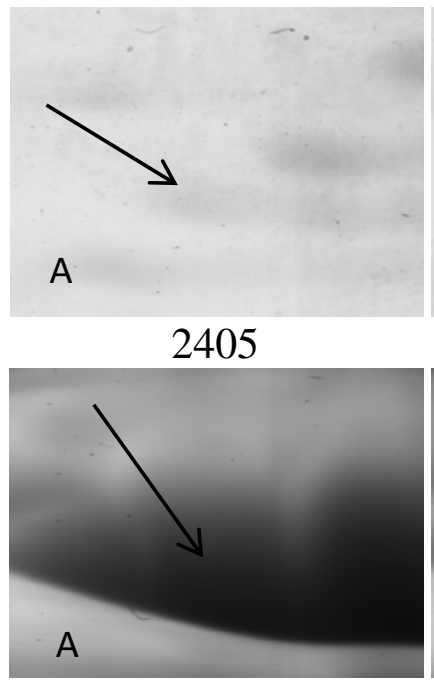

3502

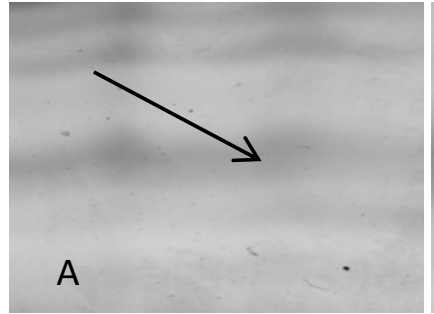

4303

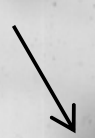

B

2405

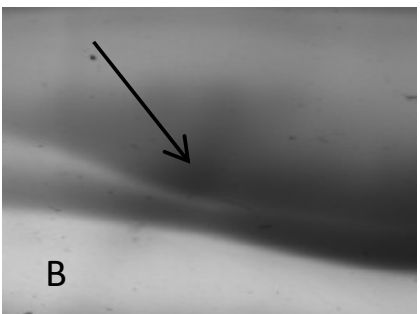

3502

B

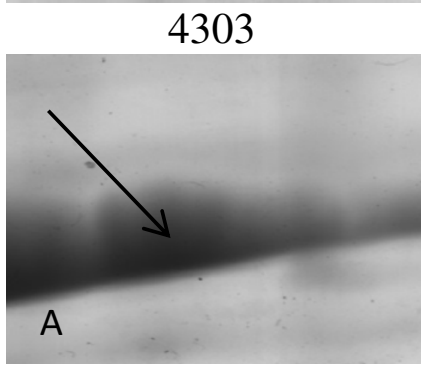

8501

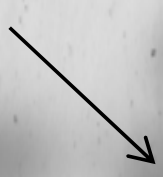

A

3102

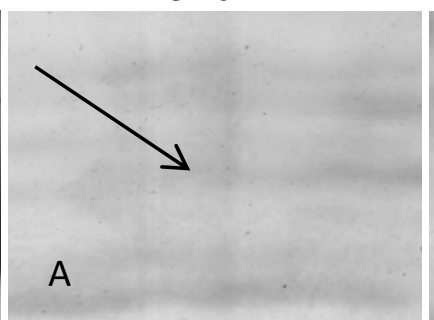

4104

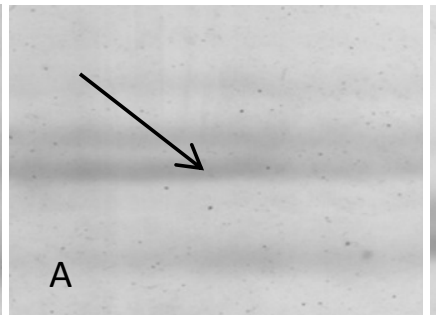

8404

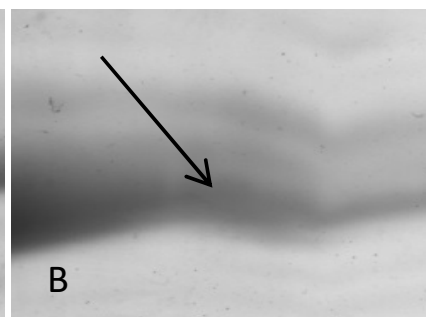

8501

Fig. 3. Representative zoomed in-gel sections, showing changes in protein abundance to 0 (A) and $300 \mathrm{mM}(\mathrm{B}) \mathrm{NaCl}$ treatment

\section{Discussion}

Reduction in shoot dry weight and plant height by the effects of salinity has also been reported in previous studies (Mer et al., 2000; Bandeh-hagh et al., 2008). Under salt stress, leaf area expansion and plant height reduced much faster than other morphological traits (Hajiaghaei Kamrani et al., 2013). Proline is one of the most important Osmolytes that synthesis in plants exposed to salt stresses and acts as an osmoprotectant. Proline concentration in plants under salt stress happens due to low activity of oxidative enzymes (Parihar et al., 2014). The increments in amount of sodium in shoot and root, as well as sodium to potassium ratio in shoot and root under salt stress have been reported previously (Dolatabadi et al., 2012). The same reports have shown a reduction in potassium level of shoot and root in salinity which is happened due to an antagonistic relationship between $\mathrm{Na}^{+}$and $\mathrm{K}^{+}$(Parida and Das, 2005). So that $\mathrm{Na}^{+}$ion abundance in the environment prevents $\mathrm{K}^{+}$ion's absorption (Bahrani, 2013).

Decreased photosynthetic activity of enzymes involved in Calvin cycle like PRK (Tanou et al., 2009), has been reported as an effective strategy to deal with salinity in various studies (Bandehagh et al., 2011; Podda et al., 2013). It seems that, the increment in the activity of PRK enzyme on assimilation pathway of carbon dioxide under salt stress is one of the main reasons for the sensitivity of this genotype to salinity.

Alpha and beta subunits of chloroplast ATP synthase are involved in the production of ATP from ADP in the presence of protons $\left(\mathrm{H}^{+}\right)$across the membranes of chloroplast. The decrement in the activity of this enzyme under salt stress has been reported in previous experiments (Kang et al., 2012; Banaei-Asl et al., 2015). Increase the activity of this enzyme under salt stress is known as a coping strategy to salt stress tolerance (Guo et al., 2012) and sensitive genotypes showed a further reduction of activity under stress (Huseynova et al., 2007).

TPI plays a key role in other metabolic pathways, such as gluconeogenesis, fatty acid biosynthesis, pentosephosphate pathway, and photosynthetic carbon dioxide fixation. Reducing the abundant of this protein has been reported in the stresses that lead to the production of oxygen free radicals (Sharma et al., 2012). 
22

Glyceraldehyde-3-phosphate dehydrogenase was one of the most important enzymes of the assimilation of carbon dioxide pathway whose activity increment as an effective strategy to tolerate the stress condition (Tanou et al., 2009) has also been reported in wheat (Kang et al., 2012), soybean (Sobhanian et al., 2010) and rapeseed root (Banaei-Asl et al., 2015).

RuBisCO played a key role in the stabilization cycle of carbon dioxide. Decrement of this enzyme's activity under salt stress in wheat (Gao et al., 2011) and rapeseed (Toorchi et al., 2014) has been reported. Salinity has a major effect on plants energy metabolism. Osmotic stress causes stomatal closure and reduces the access to carbon dioxide. Reduction of assimilation level under salt stress in glycophyte plants causes the decrement in the abundance of large/small subunit of $\mathrm{RuBisCO}, \mathrm{RuBisCO}$ activity and an increase in RuBisCO subunits destruction (Bandehagh et al., 2011; Sobhanian et al., 2011).

Plants facing salt stress decrease the rate of ATP production in order to reduce reactive oxygen species (ROS) productions which are regarded as the main source of damage to cells under biotic and abiotic stresses (Jiang $e t$ al., 2007). However, high energy production in the early stages helps plants to grow rapidly (Murad et al., 2014). On the other hand, activation of energy production pathways in order to supply the energy that is needed for biosynthesis of responded proteins, osmolytes and active salt ions transportation in the same way, seems necessary (Banaei-Asl et al., 2015). While the genotype 'Option 500 ' by reducing the production of these enzymes tried to reduce energy production and, consequently, ROS productions to keep itself away from destructive effects of salt stress. This can be the reason of 'Option500' sensitivity to salt stress.

\section{Conclusions}

'Option500' genotype by decreasing the abundance of enzymes involved in the production of energy tried to deal with the damaging effects of ROS as byproducts of energy production process. And by increasing the abundance of PRK which is an important enzyme in the pentose phosphate pathway, the production of NADPH has been increased as a reducing agent. Since this pathway is dependent on glucose 6-phosphate, and by the fact that by closure of stomata in response to osmotic stress and reduction of available carbon dioxide and decreased in the abundant of RuBisCO enzyme, glucose production was limited. Thus, this approach failed to deal with stress and it faced an initial decline in performance.

\section{Acknowledgements}

The authors like to show their gratitude to the members of Alberta Proteomics and Mass Spectrometry Facility of University of Alberta, Canada.

\section{References}

Ashraf M, Akram NA (2009). Improving salinity tolerance of plants through conventional breeding and genetic engineering: An analytical comparison. Biotechnology Advances 27(6):744752.
Ashraf M, McNeilly T (2004). Salinity Tolerance in Brassica Oilseeds. Critical Reviews in PlantSciences 23(2):157-174.

Bahrani A (2013). Effect of salinity on growth, ions distribution , accumulation and chlorophyll concentrations in two canola (Brassica napus L.) cultivars. American-Eurasian Journal of Agricultural \& Environmental Sciences 13(5):683-689.

Banaei-Asl F, Bandehagh A, Uliaei ED, Farajzadeh D, Sakata K, Mustafa G, Komatsu S (2015). Proteomic analysis of canola root inoculated with bacteria under salt stress.Journal of Proteomics 124:88-111.

Bandeh-hagh A, Toorchi M, Mohammadi A, Chaparzadeh N, Salekdeh $\mathrm{GH}$, Kazemnia H (2008). Growth and osmotic adjustment of canola genotypes in response to salinity. Journal of Food, Agriculture and Environment 6(2):201-208.

Bandehagh A, Salekdeh GH, Toorchi M, Mohammadi A, Komatsu S (2011). Comparative proteomic analysis of canola leaves under salinity stress. Proteomics 11(10):1965-1975.

Bates LS (1973). Rapid determination of free proline for water - stress studies. Plant and Soil 39:205-207.

Benincasa P, Pace R, Quinet M, Lutts S (2013). Effect of salinity and priming on seedling growth in rapeseed (Brassica napus var oleifera Del). Acta Scientiarum. Agronomy 35(4):479-486.

Bradford MM (1976). A rapid and sensitive method for the quantitation of microgram quantities of protein utilizing the principle of protein-dye binding. Analytical Biochemistry 72(1-2):248-254.

Caruso G, Cavaliere C, Guarino C, Gubbiotti R, Foglia P, Laganà A (2008). Identification of changes in Triticum durum L. leaf proteome in response to salt stress by two-dimensional electrophoresis and MALDITOF mass spectrometry. Analytical and Bioanalytical Chemistry 391(1):381-390.

Dolatabadi N, Toorchi M, Shakiba M-R, Kazemnia H, Komatsu S (2012). The response and protein pattern of spring rapeseed genotypes to sodium chloride stress. African Journal of Agricultural Research 7(5):755-763.

Dolatabadi N, Toorchi M, Valizadeh M, Bandehagh A (2016). Effect of salinity stress on some physiological traits of spring rapeseed genotypes at seedling stage. Journal of Biodiversity and Environmental Sciences $9(6): 135-142$.

Farhoudi R, Sharifzadeh F (2006). The effects of $\mathrm{NaCl}$ priming on salt tolerance in canola (Brassica napus L.) seedlings grown under saline conditions. Indian Journal of crop science 1:7478.

Gao L, Yan X,LiX, Guo G, Hu Y, Ma W, Yan Y (2011).Proteome analysis of wheat leaf under salt stress by two-dimensional difference gel electrophoresis (2D-DIGE). Phytochemistry 72(10):1180-1191.

Giannakoula A, Ilias IF (2013). The effect of water stress and salinity on growth and physiology of tomato (Lycopersicon esculentum Mil.). Archives of Biological Sciences 65(2):611-620.

Gul H, Ahmed R, Hamayun M, Qasim M (2014). Growth Performance of Canola Grown Under Different Salinity Regimes. International Journal ofEmerging Technology and Advanced Engineering 4(8):59-68.

Gunstone FD (2004). Rapeseed and canola oil: production, processing, properties and uses. Blackwell PublishingLtd.

Guo G, Ge P, Ma C, Li X, Lv D, Wang S, Ma W, Yan Y (2012). Comparative proteomic analysis of salt response proteins in seedling roots of two wheat varieties.Journal of Proteomics 75(6):1867-1885. 
Hajiaghaei Kamrani M, Hosseinniya H, Chegeni AR (2013). Effect of salinity on the growth characteristics of canola (Brassica napus L.). Technical Journal of Engineering and Applied Sciences 3(18):23272333.

Haq TU, AkhtarJ, Ali A, Maqbool MM, Ibrahim M(2014). Evaluating the response of some canola (Brassica napus L.) cultivars to salinity stress at seedlingstage. Pakistan Journal of Agricultural Sciences 51(3):571-579.

Huseynova IM, Suleymanov SY, Aliyev JA (2007). Structural-functional state of thylakoid membranes of wheat genotypes under water stress. Biochimica et Biophysica Acta(BBA) - Bioenergetics 1767(6):869-875.

Jamil M, Rehman S ur, Rha ES (2014). Response of growth, PSII photochemistry and chlorophyll content to salt stress in four Brassica species. LifeScience Journal 11(3):139-145.

Jiang Y, Yang B, Harris NS, Deyholos MK (2007). Comparative proteomic analysis of $\mathrm{NaCl}$ stress-responsive proteins in Arabidopsis roots. Journal of Experimental Botany 58(13):3591-3607.

Joseph B, Jini D (2010). Proteomic analysis of salinity stress-responsive proteins in plants. Asian Journal of Plant Sciences 9(6):307-313.

Joseph B, Jini D, SujathaS (2010). Biological and physiological perspectives of specificity in abiotic salt stress response from various rice plants. Asian Journal of Agricultural Sciences 2(3):99-105.

Kamal AHM, Kim KH, Shin KH, Choi JS, Baik BK, Tsujimoto H, Heo HY, Park CS, Woo SH (2010). Abiotic stress responsive proteins of wheat grain determined using proteomics technique. Australian Journal ofCropScience 4(3):196-208.

Kandil AA, Sharief AE, Abido WAE, Ibrahim MMO (2012). Response of some canola cultivars (Brassica napus L.) to salinity stress and its effect on germination and seedling properties. Journal of Crop Science 3(3):95103.

KangG,LiG,ZhengB, Han Q, WangC,Zhu Y, Guo T (2012).Proteomic analysis on salicylic acid-induced salt tolerance in common wheat seedlings (Triticum aestivum L.). Biochimica et Biophysica Acta (BBA) Proteins and Proteomics 1824(12):1324-1333.

Mer RK, Prajith PK, Pandya DH, Pandey AN (2000). Effect of salts on germination of seeds and growth of young plants of Hordeum vulgare, Triticum aestivum, Cicer arietinum and Brassica juncea. Journal of Agronomy and CropScience 185(4):209-217.

Miyamoto S, Oster MF, Rostle CT, Lenn EG (2012). Salt tolerance of oilseed crops during establishment. Journal of Arid Land Studies 22(1):147-151.

Munns R 2002. Comparative physiology of salt and water stress. Plant, Cell and Environment 25:239-250.

Murad AM, Molinari HBC, Magalhães BS, Franco AC, Takahashi FSC, De Oliveira NG, Franco OL, Quirino BF (2014). Physiological and proteomic analyses of Saccharum spp. grown under salt stress. PLoS ONE9(6):1-12.
Nayyar H (2003). Accumulation of osmolytes and osmotic adjustment in water-stressed wheat (Triticum aestivum) and maize (Zea mays) as affected by calcium and its antagonists. Environmental and Experimental Botany 50(3):253-264.

Parida AK, Das AB (2005). Salt tolerance and salinity effects on plants: a review.Ecotoxicology and Environmental Safety 60(3):324349.

Parihar P, Singh S, Singh R, Singh VP, Prasad SM. 2014. Effect of salinity stress on plants and its tolerance strategies: a review. Environmental Science and Pollution Research 22(6):4056-4075.

Podda A, Checcucci G, Mouhaya W, Centeno D, Rofidal V, Del Carratore R, Luro F, Morillon R, Ollitrault P, Maserti BE (2013). Salt-stress induced changes in the leaf proteome of diploid and tetraploid mandarins with contrasting $\mathrm{Na}+$ and $\mathrm{Cl}$ - accumulation behaviour. Journal of Plant Physiology 170(12):1101-1112.

Purty RS, Kumar G, Singla-Pareek SL, Pareek A (2008). Towards salinity tolerance in Brassica: An overview. Physiology and Molecular Biology of Plants 14(1-2):39-49.

Salekdeh GH, Siopongco J, Wade LJ, Ghareyazie B, Bennett J (2002). A proteomic approach to analyzing drought-and salt-responsiveness in rice. Field Crops Research 76(2):199-219.

Sharma S, Mustafiz A, Singla-Pareek S, Shankar Srivastava P, Sopory S (2012). Characterization of stress and methylglyoxal inducible triose phosphate isomerase (OscTPI) from rice. Plant Signaling \& Behavior 7(10):1337-1345.

Shirazi MU, Rajput MT, ANSARI R, Khan MA, TAHIRSS (2011). Salt tolerance in Brassica species at early seedling stage. Sindh University Research Journal-SURJ(ScienceSeries) 43(2):203-208.

Sobhanian H, Razavizadeh R, Nanjo Y, Ehsanpour AA, Jazii FR, Motamed N, Komatsu S (2010). Proteome analysis of soybean leaves, hypocotyls and roots under salt stress. Proteome science 8(19):1-15.

Sobhanian H, Aghaei K, Komatsu S (2011). Changes in the plant proteome resulting from salt stress: Toward the creation of salt-tolerant crops? Journal of Proteomics 74(8):1323-1337.

Tanou G, Job C, Rajjou L, ArcE, Belghazi M, Diamantidis G, Molassiotis A, Job D (2009). Proteomics reveals the overlapping roles of hydrogen peroxide and nitric oxide in the acclimation of citrus plants to salinity. Plant Journal 60(5):795-804.

Toorchi M, Dolati M, Adalatzadeh-Aghdam S (2014). Differentially expressed proteins in canola leaf induced by salt stress-a proteomic approach. International Journal of Biosciences 5(9):433-442.

Turan S, Cornish K, Kumar S (2012). Salinity tolerance in plants: breeding and genetic engineering. Australian Journal of Crop Science 6(9):13371348. 